\title{
INCREASED INTEREST IN MILITARY TOURISM ON SELECTED EXAMPLES FROM THE AREA OF NORTHERN AND NORTHEASTERN POLAND
}

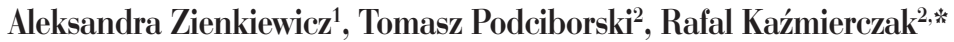 \\ ${ }^{1}$ Institute of Socio-Economic Geography and Tourism, Pomeranian University in Slupsk, Slupsk, Poland \\ ${ }^{2}$ Department of Spatial Analysis and Real Estate Market, Faculty of Geoengineering, University of Warmia and \\ Mazury in Olsztyn, Olsztyn, Poland
}

*E-mail of corresponding author: rafal.kazmierczak@uwm.edu.pl

\section{Resume}

Military tourism is one of the forms of tourism that is not sufficiently researched throughout Poland. It is only in recent years, after the period of political transformation, that interest in this phenomenon has been growing every year. This research has aimed to indicate the possibilities of military tourism development in northern and northeastern Poland. It includes an analysis of data concerning the Naval Museum in Gdynia, the "Wolf's Lair" Fortress in Gierloz and an example of a military event - an air show, which took place on the premises of the 44th Airborne Museum in Gdynia. Results of the analysis of the military tourism development in northern and northeastern Poland indicate that military sites and military-themed events attract considerable tourist traffic and play an important role in the overall development of tourism.

\section{Article info}

Received 31 January 2021

Accepted 29 March 2021

Online 13 September 2021

\section{Keywords:}

military tourism, former military sites, the attractiveness of tourist destinations, northern Poland, north-eastern Poland

\section{Introduction}

In the period before the Pandemic COVID19 in 2019, 959 museums and museum branches were active in Poland. This was $1.5 \%$ more museums than in 2018, with a total of 40.2 million visitors to all facilities. Museums organized 2.7 thousand regular exhibitions and 5.0 thousand temporary exhibitions in Poland. The number of visitors to museums per 1000 people amounted to 1048 people. Among all the museums in Poland, $77.1 \%$ belong to the public sector and they are managed by local self-governments. The characteristics of museums in Poland are presented in Figure 1 [1].

Many countries are actively pursuing tourismoriented policies to boost their economic growth [2]. Tourism means different things to different people [3]. The military tourist institutions have a significant capacity regarding both room and board services and non-accommodation services at their disposal what makes an important factor relevant to any adequate positioning in both domestic and foreign tourist market [4]. Military tourism is a segment of the tourism industry that has been attracting increasing interest in Poland and throughout the world in recent years. The growing popularity of military tourism can be attributed not only to a large number of historic military sites, in particular in northern and north-eastern Poland but also to the military-themed events and shows that attract crowds of spectators each year [5]. This term can also be analyzed in a broader context because military tourism enthusiasts have an interest in a wide variety of military objects, fortification lines, museums, exhibitions, military collections, historic military trails, cultural heritage trails and battlefields. For this reason, this form of tourism sometimes also refers to military tourism as military culture tourism, war tourism, battlefield tourism, or armament tourism [6-10]. This phenomenon was also noticed by Hrusovsky and Noeres, who claim that one can distinguish tourism products that focus on use of military equipment and products that focus on products related to historical events [11].

This study aimed to identify the opportunities for development of military tourism on the example of former military sites and structures in northern and north-eastern Poland that have been transformed into tourist destinations and recreational areas. The study focuses on two geographic areas: the South Baltic Littoral Region and the East Baltic Lakelands [12]. Military tourism was discussed on the example of the Naval Museum in Gdynia, the Wolf's Lair in Gierloz and the 44th Naval Air Base in Siemirowice. The sites and events selected for this study are located in northern 
Museums and museum branches in 2019

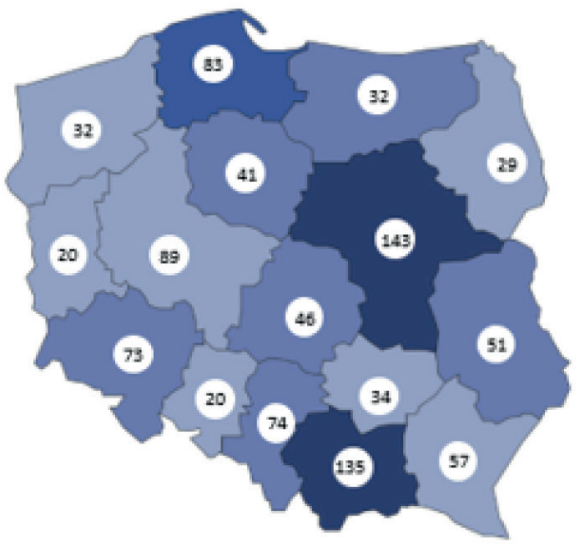

The structure of museum collection

by branch in 2019

Figure 1 Museums and museum branches in 2019 [1]

and north-eastern Poland, which abounds in military attractions on account of its rich history and strategic location. Throughout centuries, the Polish borders have been shaped by foreign powers. Numerous battles were fought and defensive structures were built in these Polish regions. The examples of military sites and objects presented in the article are nowadays used as tourist and recreation areas, as well.

The current state of research on military tourism in Poland is still insufficient, therefore this study aimed to indicate the possibilities of development of military tourism in northern and north-eastern Poland, inter alia, through analysis of tourist traffic in selected objects related to military heritage and on the example of a selected outdoor event. An important aspect of the research was also an attempt to answer questions about the current position of military tourism among other forms of tourism and whether maintaining the current trend of interest in military tourism would provide a chance for its development in Poland. The findings obtained as a result of the analyses would allow an assessment of the current functioning of the facilities and should indicate the desired direction of promotion and creation of appropriate tourist offers.

As a part of this study, research on the tourism movement of military facilities was carried out to indicate the further development of a relatively new form of tourism, which is military tourism.

\section{Literature review}

Military tourism is an atypical and relatively new form of tourism, which is also referred to as military culture tourism, war tourism, battlefield tourism and armament tourism [13-14]. Generally, one can define "military tourism" as a typical recreational and tourist program of visual, cultural and material consumption [15]. The definitions of tourism proposed in the Polish literature emphasize the cultural value of tourist destinations, which cater to the demand of visitors who have a specific interest in the military history of a given region. According to Jedrysiak and Mikos von Rohrscheidt [16], military culture tourism involves travel undertaken for self-education and personal experience, where visits to defensive structures and historic sites related to military conflict, the armed forces, weapons and military equipment are an important part of the tour program. Tourists visit fortifications, historic battlefields, areas connected with famous military leaders, military factories, museums, military shelters, bunkers and other defensive structures and they attend military-themed events and shows [17].

Tourists also have a growing interest in facilities and centers that plan military operations, former military factories, current and former military training areas, areas connected with famous military leaders, battlefields and military cemeteries. Lawin and Stasiak [18] identified the following categories of militarythemed attractions: defensive structures, battlefields, military museums, other museums with large collections of military artefacts, battle memorials, monuments commemorating historic events, areas connected with famous military leaders, war graves, military cemeteries and military events. Examples of military sites and objects presented in the article are nowadays also used as tourist and recreation areas.

According to Kowalczyk [13, 19], heritage tourism and military tourism have the following functions: historical, educational, martyrological, political, ideological, cultural, entertainment, recreation, sports and adventure. The cited author also classified military tourism attractions into those that are and are not directly related to a specific geographic location (and involve objects of material and non-material culture). Kowalczyk defined historic military tourism as all the forms of tourist activities that are undertaken - as the primary or secondary goal - to visit historic sites 
and locations connected with military activity and the military culture [20].

According to Lawin and Stasiak [18], military tourists have an interest in defensive structures such as strongholds, fortresses, citadels, bunkers, fortification lines (accessible or not accessible to tourists), battlefields, military museums, battle memorials, war graves and military cemeteries. Tourists also attend militarythemed events, such as military picnics, military fan conventions and reenactments of historical battles.

Interestingly, the concept of military tourism emerged in Polish literature only towards the end of the first decade of the 21st century. In their monograph, Lijewski, Mikulowski and Wyjrzykowski [21] referred to local history tourism, exploratory tourism, as well as man-made attractions such as historic and military sites and monuments, but they did not identify military tourism as a separate category of tourism. The cited authors remarked that one of the objectives of local history tourism is to provide visitors with an opportunity to experience sites associated with patriotic events. The Polish history and landscape abound in national memorials and areas where battles for independence were fought. These sites became widely available to the public only after the end of the Communist regime in the early 1990s. They can be expected to become important destinations for exploratory tourism shortly. Poczta [22] reported on the growing popularity of individual tourism, including adventure tourism. The above study also revealed an increase in the demand for active tourism, which enables visitors to experience pristine nature and unspoiled landscapes. Military tourism is an unconventional form of active tourism. In Poland, research into military tourism was also conducted by Chylinska [23], Cynarski [24], Stach [25], Stach et al. [26] and Zglobicki [27].

In foreign literature, the first studies on military heritage tourism were undertaken in the early 21st century [28]. Military heritage tourism was defined as a subset of heritage tourism that enables individuals to experience feelings of appreciation, awe, nostalgia and emotional attachment through contact with past events, culture and shared history. The growing popularity of military heritage sites worldwide was highlighted in a paper entitled "Commercial tourist attraction" [29]. Lemelin, Whyte et al. [30] analyzed military tourism from the indigenous perspective in areas where colonial conquest took place (Battles of Isandlwana, Rorke's Drift and Blood River). Logan and Reeves [15] remarked on the growing popularity of heritage sites related to dark events and traumatic memories, both at the national and international level. Military tourists have an interest in places and institutions that represent the legacy of painful periods in history, such as massacre and genocide sites, former prisons, places of military internment and battlefields.

Military heritage tourism was explored by Huh [11] and Chhabra et al. [31], whereas the experiences related to blood tourism and dark tourism were described by Biran and Hyde [32]. Raine [33] listed several factors that motivate individuals to visit military heritage sites. Magee and Gilmore [34] identified three categories of tourists who travel to military sites:

- visitors for whom military heritage sites have personal and emotional significance and carry a feeling of being connected to their heritage,

- ordinary tourists who do not have personal links to military heritage sites and view them merely as a leisure activity. These types of tourists primarily seek education and knowledge,

- ambivalent tourists who visit military heritage sites to "see it to believe it" [35].

Publications exploring the historical background of military events, such as Military Pomerania between the 12th and the 21st century [36] and Military Artefacts of Pomerania [37] play an important role in the literature on military tourism in northern and north-eastern Poland. Other notable publications in this field of research include "Squandered Opportunities" by Pradzynski [38], Military Artefacts of Polish Military Formations and the Polish Army from 1914-1922 [39], Military Museology [40-41], Underwater Military Vehicles and Artefacts in the Gulf of Gdansk [42], as well as articles by Piatek [43], Jurga [44], Lamparska and Malik [36] and Jarosz [37]. Encyclopedia of Military Technology [5] and Military Artefacts of Pomerania from the 19th to the 20th century by Drzewiecki and Rozycki [45] also make valuable contributions to the literature on military heritage.

Although military tourism is slowly gaining popularity all over the world, as evidenced by quite a rich literature on the subject, in Poland it is still niche tourism. Even though there are quite a lot of studies on military heritage sites, so far there has not been enough research on the state of tourism in these sites. Most of the research includes historical or architectural analyses. Bearing in mind the above-mentioned premises, the authors hope that this article will expand the knowledge on possibilities of growth and possible development of tourism in tourist facilities of military importance, or even greater interest in the participation of tourists in military outdoor events.

\section{Materials and methods}

Research methods and techniques for this study had to be carefully selected to address the unique character of the research problem and the relevant scarcity of data sources. The research methodology of this study included several stages:

1) Research project and case selection (objects, events)

In the first stage of the research, the objects and events related to the military heritage located in northern and north-eastern Poland were analyzed. An important determinant was the availability of tourist 
traffic statistics in the above-mentioned objects and the possibility to visit these places in person.

2) Review of literature in the light of the state of development of research on military tourism

To determine the research subject matter of the presented article, an analysis of the literature was undertaken in terms of issues related to military tourism. This allowed for the initial systematization of knowledge describing phenomena related to this type of tourism.

3) Collection and analysis of source data

A very big challenge is to obtain information on museum resources and statistical data for monitoring the volume of tourist traffic. There is no unified system for managing museums and historical events. Obtaining information relies on direct contact with museum directors. There are no standards for storing and making tourist data available. This causes very high difficulties in managing the tourism sector.

In the presented study on the issue of military tourism, methods based on the secondary information contained in lists and registers provided by the institutions were used: Naval Museum in Gdynia, Centre for Historical and Natural Education "Wilczy Szaniec" of Srokowo Forest District and data of Gdynia Naval Aviation Brigade. The scope of collected and analyzed statistical data included information on the volume of tourist traffic in the years 1996-2019 (in the case of "Wilczy Szaniec" only the period 2017-2019, which is related to the change of ownership of the facility and the lack of data for earlier years) and in the months January-February 2018 in the case of the Naval Museum in Gdynia.

Observations, interviews and photographs were highly valuable sources of primary information. Due to considerable variations in behavior of individual tourists and the general scarcity of statistical data, field observations and interviews conducted during the military-themed events, such as the Open Day at the 44th Naval Air Base in Siemirowice, provided highly valuable insights. The observations and an interview with the press officer of the Gdynia Navy Airborne Brigade on 1.06.2018 allowed authors to determine what properties of the objects and events proposed for research are of interest to military tourists. Designed in the research and then placed in the study photographs of selected objects and phenomena are intended to show, on the one hand, the diversity and attractiveness of the above-mentioned places and, on the other hand, help to quickly estimate the number of tourists located in the area. They also prove the interest of the audience in particular elements of shows/exhibitions/buildings. Of course, due to lack of space, this article contains only a few illustrations showing only selected cases.

The authors also relied on the Google Trends website to analyze the popularity of search queries for the Wolf's Lair in Gierloz across geographic locations. The second advantage of this method was the possibility to estimate the amount of general interest in the selected tourist attraction on a global scale.

\section{Results}

\subsection{Development of military tourism on the example of the Naval Museum in Gdynia}

According to Jedrysiak and Mikos von Rohrsscheidt [16], attractive museums exert a direct impact on the way visitors perceive reality and influence tourist traffic. Museum visits have become a popular pastime for millions of people. Military museums play a very important role in a civic society by creating a direct link to the past, acting as repositories of knowledge and by preserving historical resources and memories of

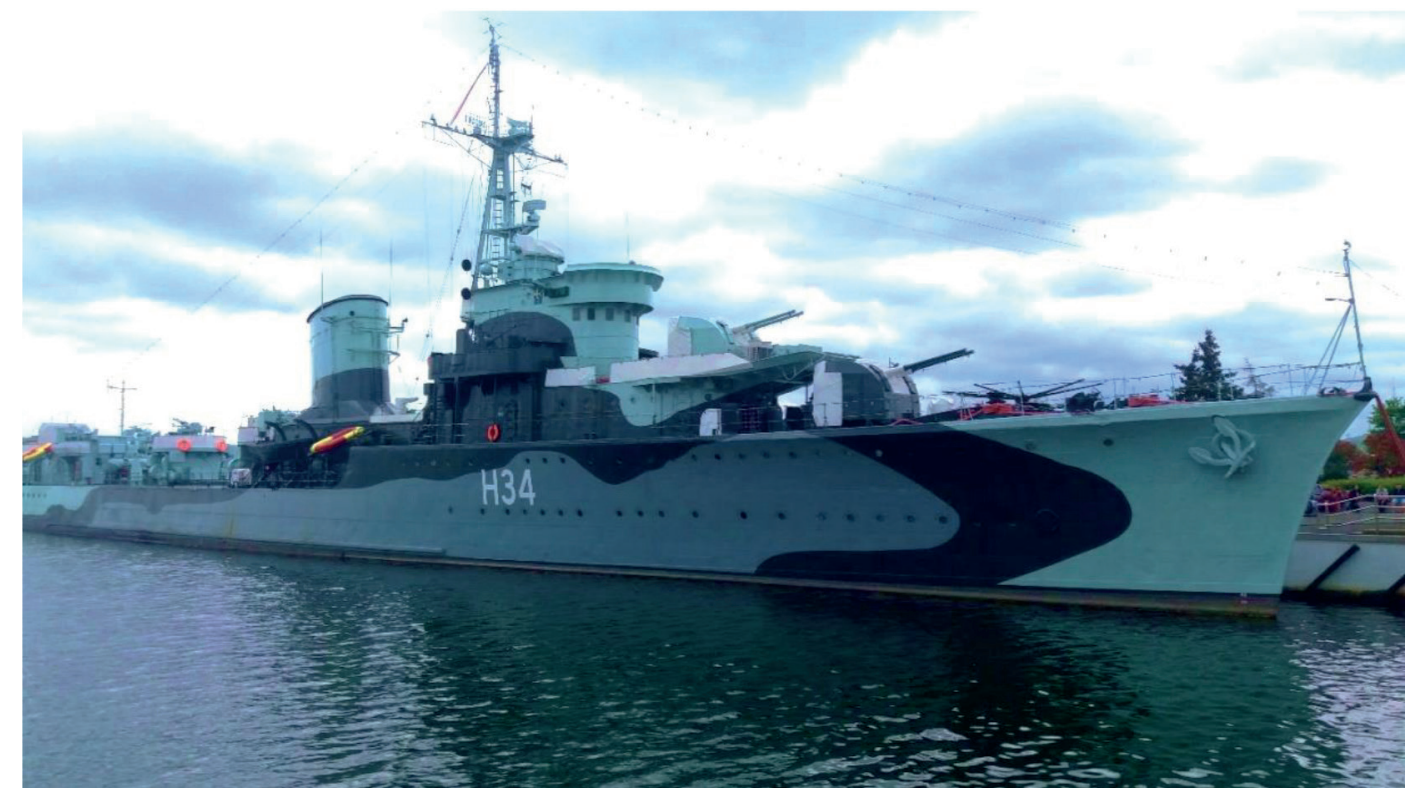

Figure 2 ORP Blyskawica in Gdynia 


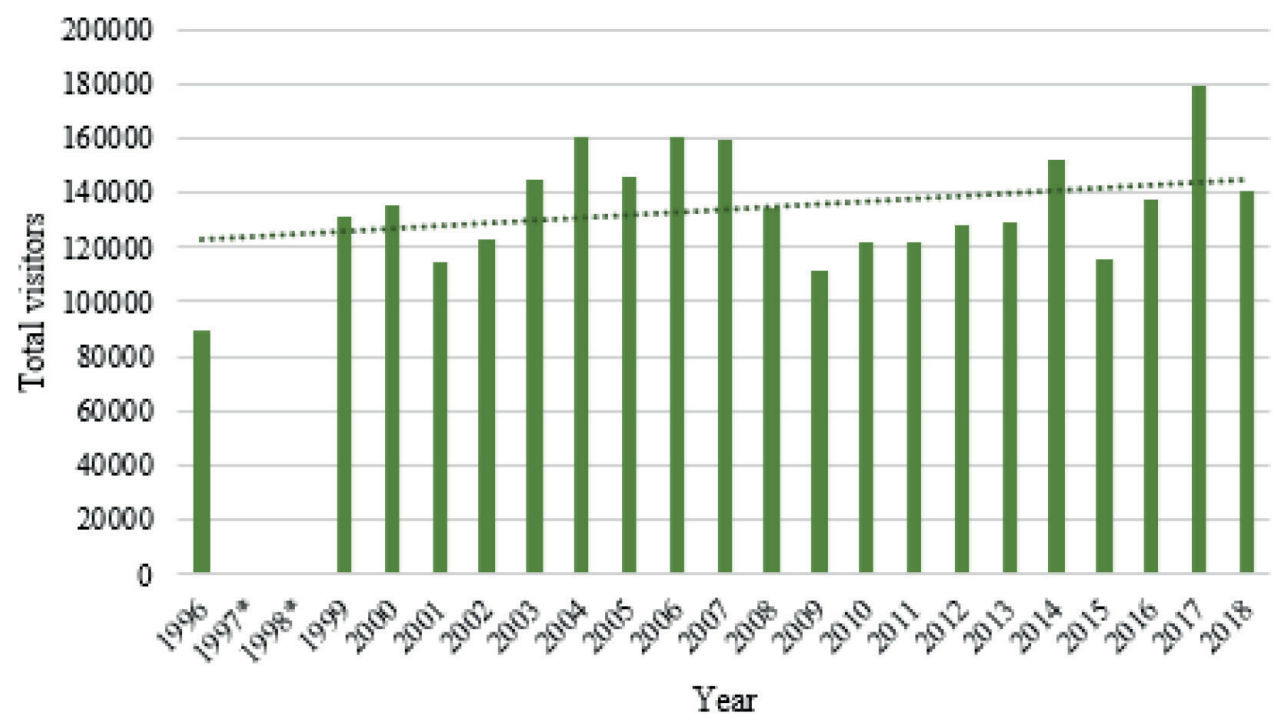

Figure 3 The number of visitors to the Naval Museum in Gdynia in 1996-2018, based on data from the Register of the Naval Museum in Gdynia

the past for future generations [27]. Military museums amass collections of armor and weapons spanning many centuries, where some collections are dedicated to specific battles fought in the remote past [15,42]. According to Jedrysiak [17] and Rottermund [46], museums play a special role in social life due to their continued existence, as well as the fact that the esthetic and educational value of the displayed objects has been scientifically substantiated [14, 16]. The Naval Museum in Gdansk is one of such facilities. Its collection consists of around 50,000 objects divided into several categories, including military artefacts, models, memorabilia, art, ship equipment, archives and photographs. Ship models, flags, streamers, vessel names and symbols on ship hulls, ship bells and other naval objects are among the museum's greatest attractions. One of the most highly prized objects in the museum's collection is ORP Blyskawica (Lightning), a destroyer ship that served in the Polish Navy during World War II. The ship was converted into a museum in 1976 and it is open to the public in the Kosciuszki Square in Gdynia (Figure 2). The ship boasts a vast collection of military equipment and memorabilia linked to crew and history during World War II. ORP Blyskawica serves representative functions during the national ceremonies and conferences [16].

Tourist traffic and seasonal changes in tourism demand are the key indicators of tourism development, including military tourism [10, 47-48]. An analysis of tourist traffic in the Naval Museum in Gdynia revealed that the number of visitors has increased considerably from 89,000 in 1996 to nearly 140,400 in 2018 (Figure 3 ). Tourist traffic peaked in 2017 when the number of visitors was approximately 180,000 . These data indicate that the popularity of military tourism continues to increase each year in Poland.

Seasonal demand for tourism is an important measure of visitors' interest in a given region or tourist attraction. These data influence development of various types of tourism and the growth of tourism in general. Analyses of the seasonal distribution of tourist traffic provide valuable insights for tourism operators, for example by identifying the most profitable months for organizing mass events such as military-themed shows.

The data presented in Figure 4 indicate that the Naval Museum in Gdynia and ORP Blyskawica attract the highest number of visitors between May and September. Considerable differences in the volume of tourist traffic can be observed between months with the lowest and highest numbers of visitors. In 2018, monthly tourist traffic ranged from around 500 visitors in February ( $0.9 \%$ of annual traffic) to around 14,000 in July (28.4\%) in the Naval Museum in Gdynia and from 0 visitors in February-April to around 15,800 in July $(28.3 \%)$ in ORP Blyskawica. Combined tourist traffic in both sites was the lowest in February (500 visitors, $0.3 \%$ of annual traffic) and the highest in July $(39,800$ visitors, $28.3 \%$ ).

The study also revealed that ORP Blyskawica attracted more visitors (by 42,500) than the Naval Museum in 2018. This difference could be explained by the ship's convenient location along the main promenade in the Gdynia harbor, as well as the novel experience of touring an authentic warship.

\subsection{Military tourism in the Wolf's Lair Bunker in Gierloz}

The Wolf's Lair in Gierloz is unquestionably one of the greatest tourist attractions in the Mazury and Suwalki Lakeland in northern Poland [49]. The bunker served as one of Adolf Hitler's first military headquarters on the Eastern Front. It was built near the village of Gierloz, $9 \mathrm{~km}$ away from the East Prussian town of Rastenburg (Ketrzyn), on the territory of present-day Poland. The Wolf's Lair is one of the best- 

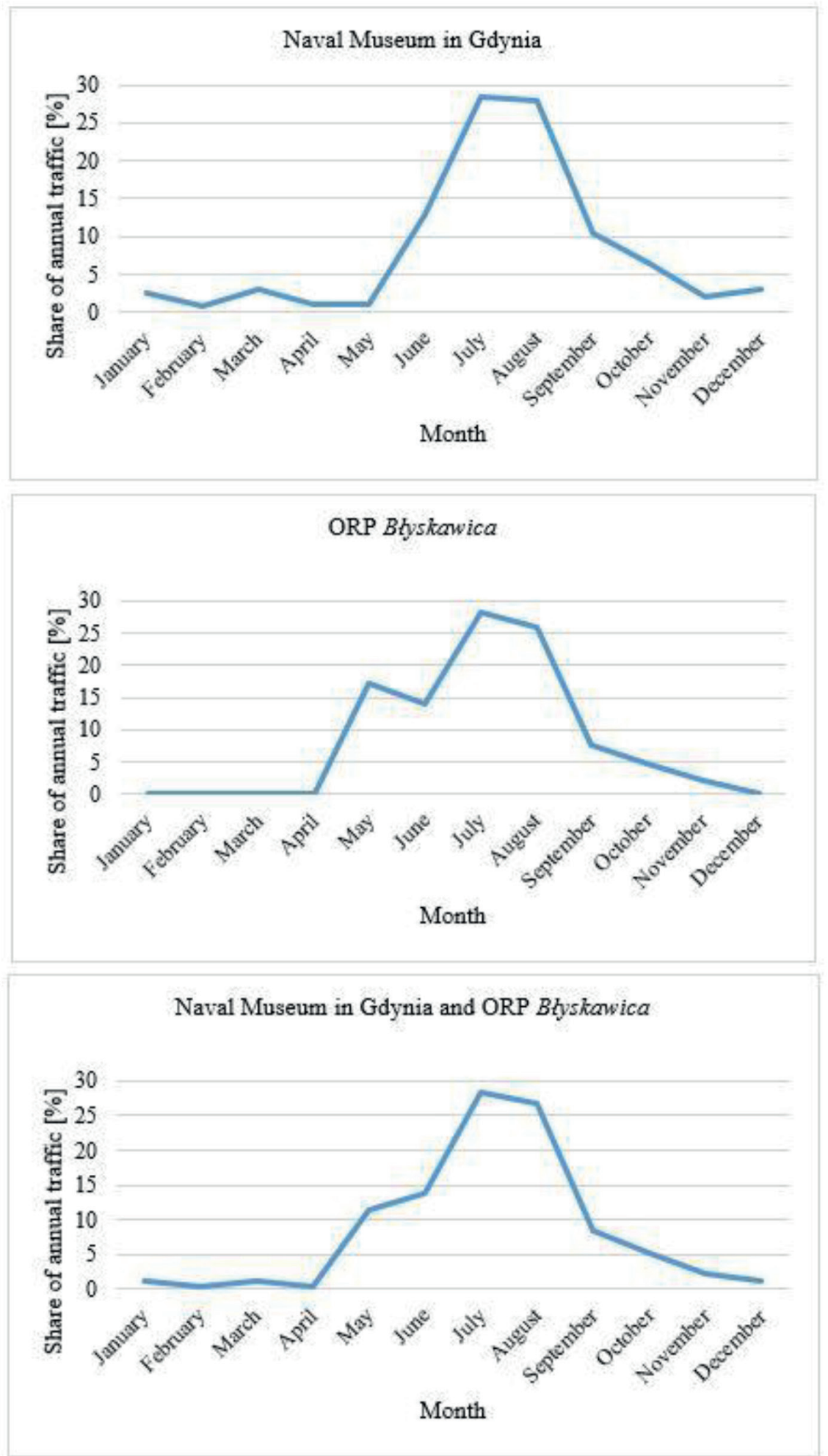

Figure 4 Seasonal distribution of tourist traffic in the Naval Museum in Gdynia in 2018, based on data from the Register of the Naval Museum in Gdynia

known high-security historic military sites in Europe. It was originally composed of nearly 200 buildings, including security bunkers, residential bunkers, air-raid shelters, military barracks, two airfields, a power plant and a railway siding. The entire complex had access to main water, heating and ventilation systems. Other military command centers and headquarters of German military institutions were built in the vicinity [44]. In 2017, the Wolf's Lair was transformed into the Historical and National Education Center of the Srokowo Forest District.

An analysis of the site's tourism attractiveness revealed that Wolf's Lair is characterized by considerable functional cohesion due to the presence of nearly twenty 


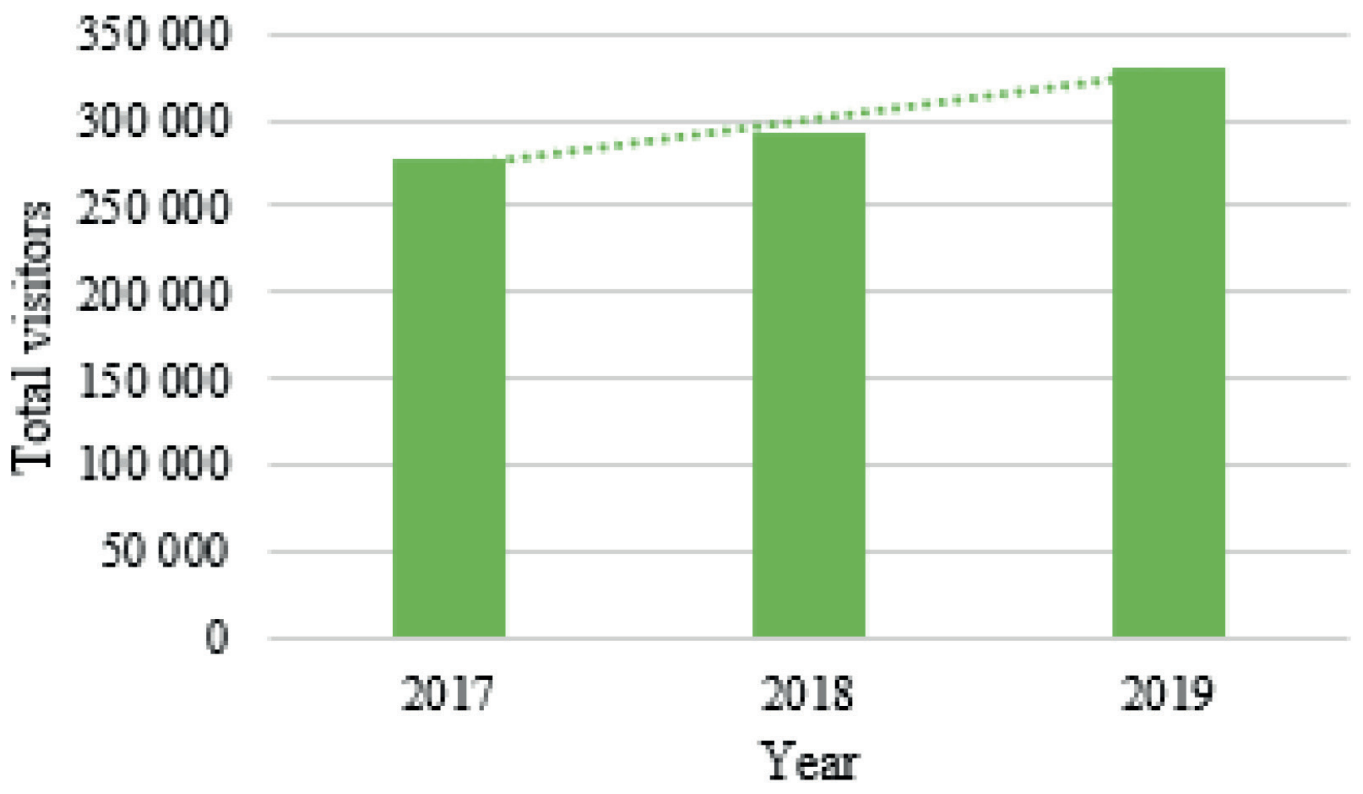

Figure 5 The number of visitors to the Wolf's Lair in Gierloz in 2017-2019, based on the data of the Wolf's Lair Historical and Natural Education Center of the Srokowo Forest District

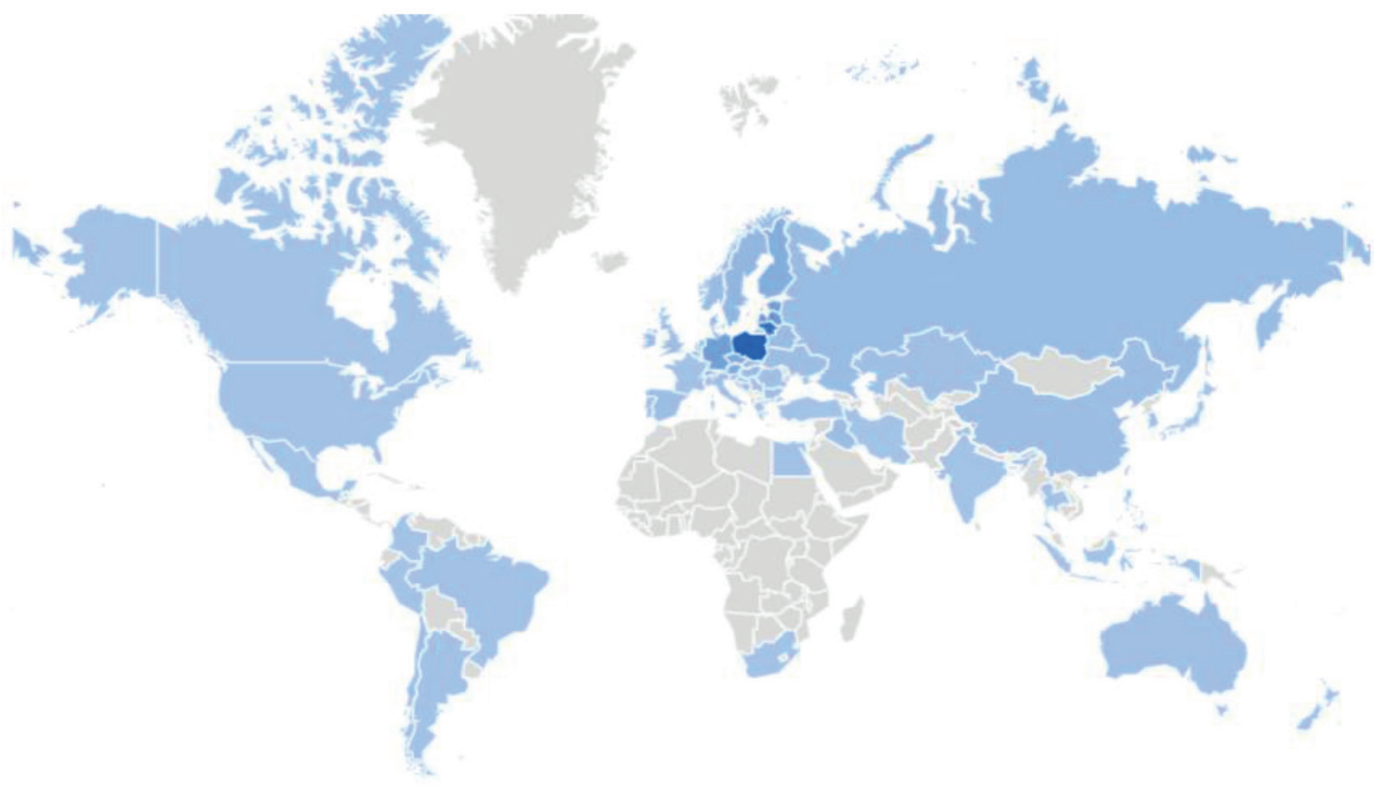

Figure 6 Geographic distribution of queries containing the words "Wolf's Lair (historic site in Gierloz)" in Google Trends between 1 January 2010 and 1 January 2020, [50]

attractions, extensive access to tourist information, guided tours, restaurants and a car park [10]. The Wolf's Lair enjoys growing popularity among tourists (Figure 5). In 2017, it was listed by The Telegraph as one of the 25 most popular tourist destinations in Eastern Europe. Nearly 276,300 tourists visited the site in 2017 and the number of visitors increased by more than 50,000 to nearly 330,000 by the end of 2019 .

According to Srokowo Forest District data, nearly $40 \%$ of visitors attended guided tours of the Wolf's Lair and a total of 11,000 guided tours have been held since 2017. The remaining visitors toured the site individually with use of a mobile guide application, printed guides and maps that can be purchased on the site. The main buildings and attractions are very well signposted, which facilitates tourist movement. The Wolf's Lair attracts visitors from various regions of the world and according to Srokowo Forest District data, foreign tourists, mostly from Germany, generated a third of tourist traffic on the site. The number of Google searches related to the Wolf's Lair also testifies to the site's considerable popularity (Figure 6).

An analysis of Google Trends queries containing the words "Wolf's Lair (historic site in Gierloz)" between 1 January 2010 and 1 January 2020 revealed that this military site attracted the interest of Internet users 




Figure 7 Orlik Aerobatic Team flying PZL-130 turboprop trainer aircraft during the Open Day of the 44th Naval Air Base in Siemirowice on 16 July 2016

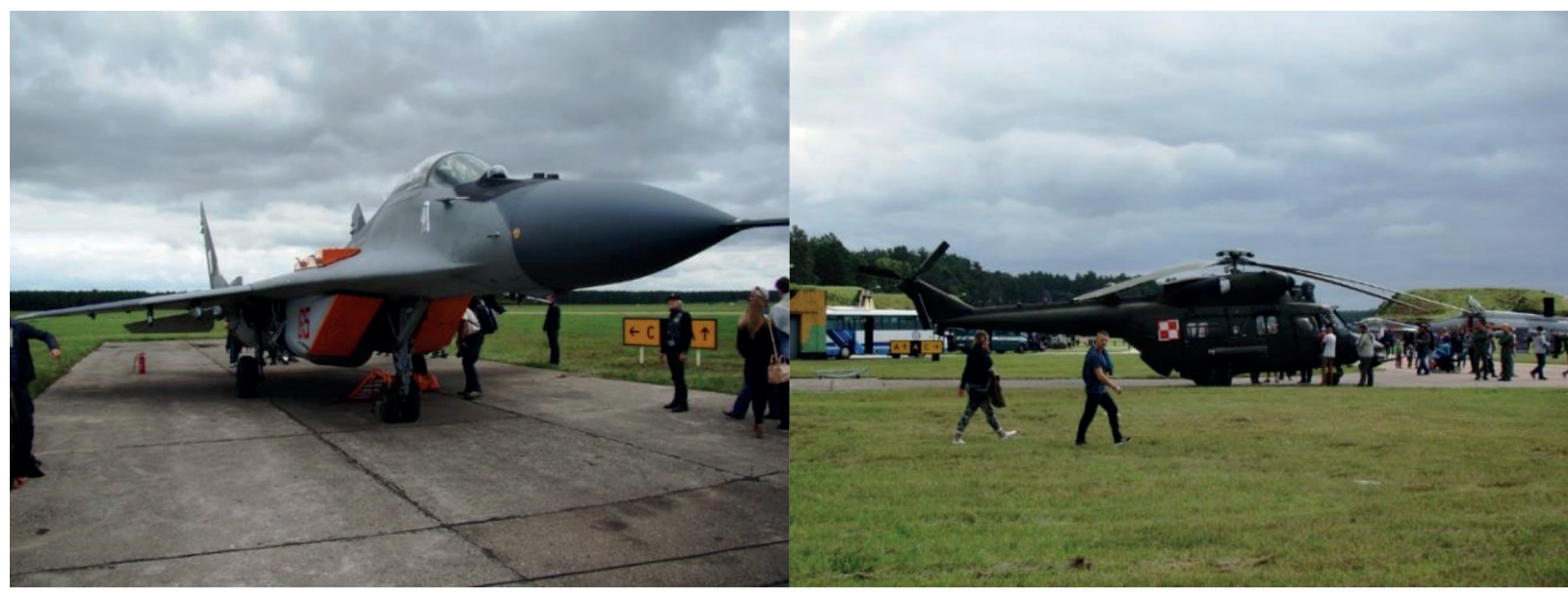

Figure 8 Exhibition of naval aircraft during the Open Day of the 44th Naval Air Base in Siemirowice on 16 July 2016

from 60 countries around the world. The highest number of searches in the analyzed period was made in Poland, Lithuania, Latvia, Germany, Estonia, Czechia, Austria, Finland, Slovakia, Luxembourg, Sweden, Denmark and Switzerland.

\subsection{Open Day in the 44th Naval Air Brigade in Siemirowice}

Field events and shows are among the greatest attractions for tourists with a special interest in military heritage. The Open Day and Air Show in the 44th Naval Air Base in Siemirowice was one of such events in 2016.

The 44th Kaszuby-Darlowo Naval Air Base was established on 1 January 2011 when the 29th Darlowo Air Force Squadron and the 30th Kaszuby Air Force Squadron were incorporated into the 44th Naval Air Base. The naval base comprises the Kaszuby Aviation Group in Siemirowice, which operates An-28B1R and An-28B1RM Bis patrol and reconnaissance aircraft and An-28E environmental monitoring aircraft and the Darlowo Aviation Group, which operates Mi-14PL anti-submarine helicopters, Mi-14PL/R and W-3RM rescue helicopters and $\mathrm{Mi}-2$ helicopters. The main tasks of the 44th Naval Air Base include maritime reconnaissance; recognition and indication of targets to marine units; search, tracking and destruction of submarine warfare; search and rescue missions; and environmental monitoring of the Polish Exclusive Economic Zone of the Baltic Sea. In the naval air bases in Siemirowice and Darlowo, patrol aircraft and rescue helicopters are on round-the-clock duty as a part of the national surveillance system, the NATO reconnaissance system and the national marine and aviation rescue system. The base can be visited by members of the public on open days and military-themed events and shows are held every five years to celebrate milestone anniversaries.

The Open Day at the 44th Naval Air Base in Siemirowice, held on 16 July 2016 between 9:30 a.m. and 4:30 p.m., attracted more than 10,000 visitors, most enthusiasts of military technology, military aircraft and vehicles. The event was organized to celebrate the 60th anniversary of the first aircraft landing in Siemirowice and the 96th birthday of the Polish Navy. The air show (Figure 7) involved presentations of naval aircraft such as Mi-14PL anti-submarine helicopter, W-3RM Anakonda rescue helicopter, MiG-29 and F-16 jet fighter aircrafts and Mi-24 attack helicopter. The aerobatic 
maneuvers performed by the two Su-22 fighter-bomber aircrafts and performance of the Orlik Aerobatics Team involving seven PZL-130 turboprop trainer aircrafts also attracted considerable interest.

The event also involved an exhibition of military equipment, including the Blenda anti-aircraft artillery system, armored vehicles of the 1st Mechanized Battalion in Lebork and state-of-the-art weapons of the Naval Missile Unit (Figure 8).

Open days are usually held every five years, but the Naval Air Base in Siemirowice does not keep statistical records of these events, which is why the number of spectators cannot be accurately defined. However, according to the press officer of the Naval Air Brigade in Gdynia, the popularity of military-themed events and air shows in Siemirowice continues to increase steadily.

\subsection{Transport accessibility of selected sites}

The most important role of transport in the tourism sector is to provide access for tourists to the places they visit. Transport is one of the key elements influencing the attractiveness of a given area in terms of possibilities for development of tourism [21, 51]. The basis for appropriate functioning of transport is a sufficiently developed network of railways and motorways, as well as its good technical conditions and appropriate frequency of bus and railway connections between particular locations. Nowadays, access to airports and seaports is also becoming increasingly important [13, 52-53]. A very important aspect in the light of the present research is therefore the indication of the communication accessibility of the selected ones of military importance.

The Museum of the Navy, located in Gdynia, has relatively good communication accessibility. From the research conducted into the location of tourist attractions in the geographical space of Pomorskie Voivodeship, it can be concluded that the convenience of communication, in this case, lies in the proximity of transport corridors and hubs of regional, supra-regional and international significance. The communication accessibility of the above-mentioned museum is largely based on the existence of corridors of European importance (Baltic-Adriatic Corridor, Northern Corridor/ Northern Seaside Corridor) and the existence of the national Lakeland Corridor (based on national road No. 22 and railway line No. 203). European conditions also include connections within the Trans-European Transport Networks (TEN-T) running through the Pomeranian Region, including priority lines, i.e.: the E65 railway line (Gdansk - Warsaw - Brno/ Bratislava - Vienna), A1 motorway (Gdansk - Brno/ Bratislava - Vienna), motorways of the sea in the Baltic Sea, "Galileo" satellite navigation and positioning system. Short sea shipping and small harbors and ports are in the immediate vicinity. The TEN-T network priorities also include waterways, i.e. the E-40 (Vistula - Bug Dniester) and E-70 (Hohensaaten lock - Oder - Warta - Notec - Bydgoski Canal - Brda - the Vistula - Nogat - Vistula Lagoon - Baltic Sea). Another possibility is to reach the above-mentioned museum with the partial use of the sea transport (port in Gdynia and Gdansk). In Gdansk's Matarnia district there is the Lech Walensa Airport, which was opened in 1974 and occupied an area of 240 ha. It plays the role of a TEN-T network node of both national and international importance [10].

Transport accessibility of "Wilczy Szaniec" Fortress in Gierloz, located in Warminsko-Mazurskie voivodeship, Ketrzyn poviat, Ketrzyn commune, is less developed.
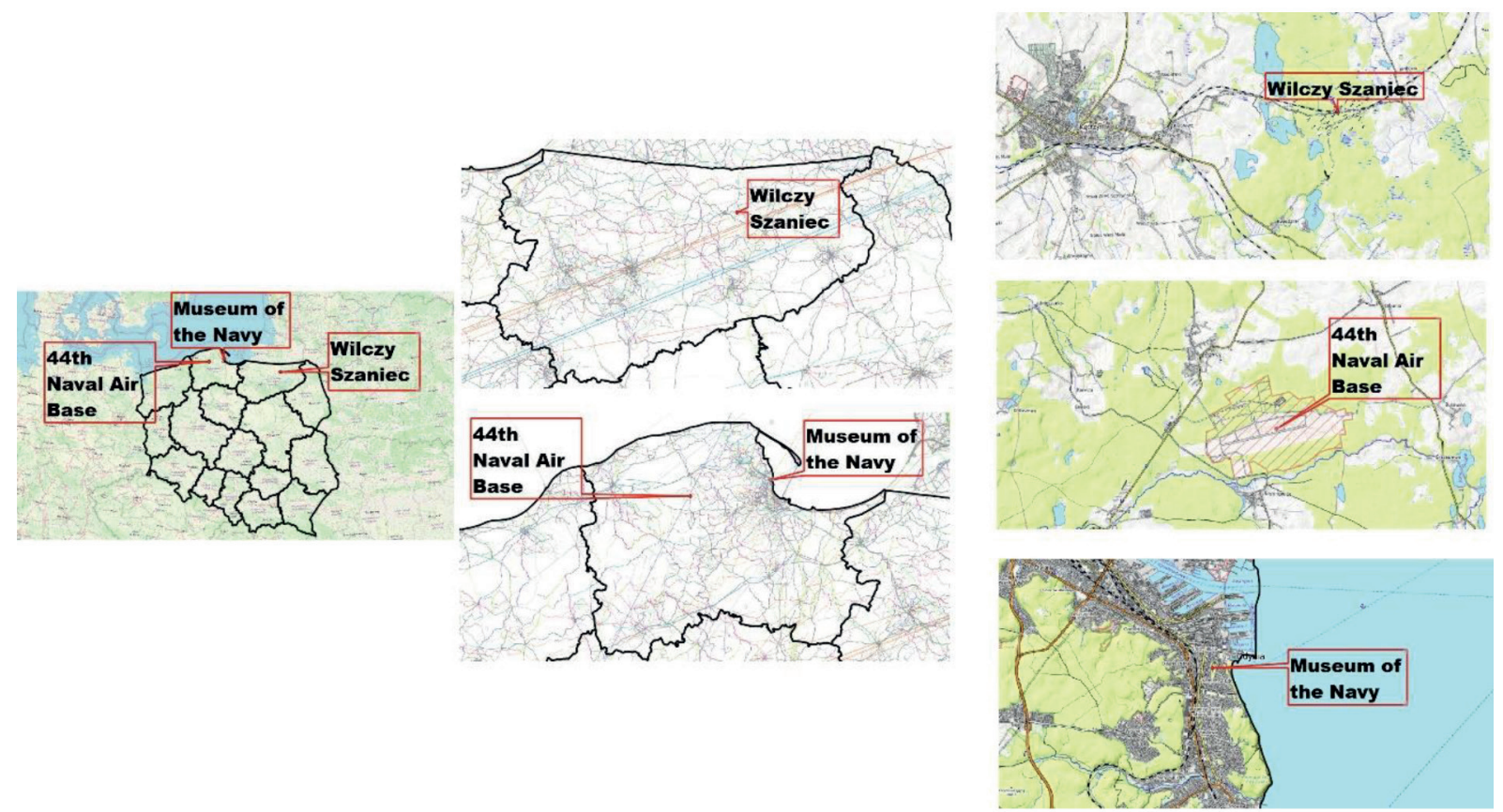

Figure 9 Overview map with the transport network 
The main reason for this situation is the peripheral location of the province itself, as well as poorly developed internal and external communication. Undoubtedly, the following factors are responsible for this situation: natural environment requiring protection, rather low population density, dispersed settlement network and low investment attractiveness of the region [48]. One of the problems of the voivodship is also the existence of numerous objects and post-military areas, which require reclamation and introduction of new functions. Direct access to "Wilczy Szaniec" is very difficult. The site was intentionally built in a place that is difficult to access - it is situated far from main communication routes, in a forest area that provides natural protection for military facilities. The Great Masurian Lakes located to the east of the forest are also a significant barrier.

The 44th Naval Air Base, on the other hand, was built in Siemirowice, in the Pomeranian Voivodeship, Lebork County, in the municipality of Cewice. The military facility, where air shows were organized in 2016, is generally characterized by good communications, although it is approximately $11.8 \mathrm{~km}$ from the national road S6/international route E28. Siemirowice is furthermore located approximately $45 \mathrm{~km}$ from the nearest airport and seaport. Furthermore, the 44th Naval Air Base is located close to the same transport corridors of national and international importance as the Naval Museum in Gdynia.

In terms of accessibility to particular sites of military significance, the general population potential is also of considerable importance, as is the presence of adequate tourist infrastructure (e.g. hotels, restaurants and other facilities) in the vicinity of the listed tourist attractions. Figure 9 shows an overview map with the location of the studied objects with the transport network.

\section{Discussion}

The problem related to the management of, inter alia, museum resources and information on the increase in use of the results of socio-economic research in shaping national and regional development policies until 2028 was noted by the Ministry of Culture and National Heritage in Poland. Among other things, the lack of statistical data on tourism and tourism resources causes difficulties in creating development plans. Examples of museums, discussed in the article, represent regions that base their functioning, among other things, on tourism. To solve this problem of access to information, the National Centre for Research and Development has announced an ordered project (GOSPOSTRATEG V), which includes digital cultural heritage. The project envisages the creation of a "National aggregator of data on digital cultural heritage". A diagnosis concerning the resources of Polish culture will facilitate its management on a national scale. All the development works should begin with an inventory of resources. Therefore, it is, as the first of all, planned to carry out a comprehensive survey on the condition of digital cultural resources in Poland, which are in possession of the state and selfgovernment cultural institutions, scientific units and other entities collecting digital cultural resources. The second task will be to estimate the resources that should be digitized. As a result of this work, an IT platform will be created that will make it possible to create compilations and analyses of the resources held. The analyses carried out on selected museums confirmed the lack of a uniform system for making data and information available [54].

The three discussed examples confirm that narrow thematic specialization in the case of museums and thematic events can attract a very large crowd Managers of museums and historical events should use publicly available IT tools (e.g. google trends) to monitor in which regions and countries a given event or museum attracts the most interest. This will allow choosing the right promotional strategies. At the same time, taking into account the very high potential of military tourism, it would be advisable to set up a consortium or cluster to improve recognition and increase the effectiveness of reaching tourists. Global trends show that such a cooperation improves possible audience reach.

\section{Conclusions}

Historic military sites and tourist destinations in Poland, featuring unique military artefacts and weapons, including objects that are related to the history of World War II, should drive the development of military tourism. The presented examples of military heritage sites in northern and north-eastern Poland indicate that military tourism is a rapidly growing segment of the tourist industry.

The main objective of the research was to indicate the possibilities of military tourism development in north and north-eastern Poland. The conducted studies in this area included an analysis of tourist traffic in selected objects related to military heritage and on the example of an outdoor event. This made it possible to indicate the current trends of interest in this form of tourism.

Military museums, including the Naval Museum in Gdynia, historic military sites such as the Wolf's Lair in Gierloz, military-themed events and open day shows organized by military bases and former military facilities are important sources of historical knowledge.

The research conducted in the objects selected for analysis shows that currently there is an increase in interest in military tourism, which is manifested in the increased tourist traffic.

An analysis of the tourist traffic in military heritage sites and military-themed tourist destinations points to the steady growth of military tourism in Poland. Military 
bases and historic sites attract growing numbers of visitors who have an interest in history and the armed forces. These tourist destinations are often linked with acts of heroism and they promote patriotic values.

This study revealed an increase in tourist traffic in the analyzed tourist destinations. The number of visitors to the Naval Museum in Gdynia increased from 89,000 in 1996 to nearly 140,400 in 2018. In the Wolf's Lair Historical and Natural Education Center of the Srokowo Forest District, tourist traffic increased from 276,300 in 2017 to nearly 330,000 in 2019. The air-show during the Open Day at the 44th Naval Air Base in Siemirowice in 2016 also enjoyed immense popularity and attracted more than 10,000 spectators.

Another aspect of the research was also an attempt to answer the question of what place military tourism currently occupies among other forms of tourism in Poland and whether maintaining the current trend in the volume of tourism would be an opportunity for its further development. Taking into account the statistics presented above, the authors of the article agree that there is a high probability that military tourism may occupy a very important place in the structure of tourism forms in Poland because it combines the advantages of cultural tourism with other forms of tourism and often concerns important aspects related to history. It is also possible to further increase interest in this form of tourism, which may lead to a situation where it will become one of the most popular forms. Unfortunately, the current epidemiological situation in Poland and the world also imposes restrictions on museum objects in terms of limiting their activity. Therefore, the present research needs to be thoroughly deepened regarding further qualitative and quantitative studies of tourist traffic and research on the impact of the SARS-CoV-2 coronavirus epidemic on the volume of this traffic.

The authors hope that this article will expand the knowledge on possibilities of growth and possible development of tourism in military heritage sites and will contribute to the even greater interest of tourists in military outdoor events.

\section{References}

[1] Statistical office in Krakow. Activity of museums in 2019 [online] [accessed 2021-03-29]. Available from: https:/stat.gov.pl/en/topics/culture-tourism-sport/culture/activity-of-museums-in-2019,8,2.html

[2] NADEEM, M. A., LIU, Z., XU, Y., NAWAZ, K., MALIK, M. Y., YOUNIS, A. Impacts of terrorism, governance structure, military expenditures and infrastructures upon tourism: empirical evidence from an emerging economy. Eurasian Bus Review [online]. 2020, 10, p. 185-206. eISSN 2147-4281. Available from: https://doi. org/10.1007/s40821-020-00152-y

[3] MCKERCHER, B. Differences between tourism and recreation in parks. Annals of Tourism Research [online]. 1996, 23(3), p. 563-575. ISSN 0160-7383. Available from: https://doi.org/10.1016/0160-7383(96)00002-3

[4] VENTER, D. Examining military heritage tourism as a niche tourism market in the South African context. African Journal of Hospitality, Tourism and Leisure. 2017, 6(1), p. 1-19. ISSN 2223-814X.

[5] Encyclopedia of military technology / Encyklopedia techniki wojskowej (in Polish). Warszawa: Wydawictwo Ministerstwa Obrony Narodowej, 1987.

[6] FINNEY, P. Miniature: finding the Fuhrer bunker. Rethinking History [online]. 2007, 11(2), p. 287-291. ISSN 1364-2529, eISSN 1470-1154. Available from: https://doi.org/10.1080/13642520701270526

[7] WALSH, K. The representation of the past: museums and heritage in the post-modern world. London: Routledge, 1992. ISBN 9780415079440.

[8] RANISAVLJEVIC, M., TESANOVIC, B., NIKEZIC, S. Military tourist institutions within the tourist offers of Serbia. International Journal of Economics and Law [online]. 2017, 7, p. 133-146. ISSN 2217-5504.

[9] SADOWSKI, P. Battlefields of 1939 Campaign in southern Lesser Poland as destinations of military cultural tourism. In: Tourism role in the regional economy. Vol. 7. WYRZYKOWSKI, J., MARAK, J., DROZDOWSKA, M. (eds.). Wroclaw: University of Business in Wroclaw, 2016. p. 213-226.

[10] ZIENKIEWICZ, A., PODCIBORSKI, T. The assessment of attractiveness and accessibility of historic military facilities utilized for the needs of tourism. Acta Scientiarum Polonorum-Administratio Locorum [online]. 2019, 18(3), p. 335-343. ISSN 1644-0749, eISSN 2450-0771. Available from: https://doi.org/10.31648/aspal.4186

[11] HUH, J. Tourist satisfaction with cultural/heritage sites: the Virginia historic triangle. (Master's Thesis). Blacksburg: Virginia Polytechnic Institute and State University, 2002.

[12] KONDRACKI, J. Regional geography of Poland / Geografia regionalna Polski (in Polish). Warszawa, 2002. ISBN 9788301160227.

[13] KOWALCZYK, A. Contenporary cultural tourism / Wspolczesna turystyka kulturowa (in Polish). In: Cultural tourism. Geographic view / Turystyka kulturowa. Spojrzenie geograficzne. KOWALCZYK, A. (ed.). Warszawa: Uniwersytet Warszawski, 2008.

[14] Military Pomerania XIIth-XXIth centuries / Pomorze militarne XII-XXI wiek (in Polish). In: Materials from the scientific session November 27, 2003 in the Pomeranian Dukes ' Castle, Szczecin "Borderland” Society, Faculty of 
Humanities of the University of Szczecin, State Archives in Szczecin, Sczecin, 2004 KOZLOWSKI, K., RYMAR, E. (eds.)

[15] LOGAN, W., REEVES, K. Places of pain and shame. Dealing with difficult heritage. Oxon: Routledge, 2009. ISBN 9780415454506.

[16] JEDRYSIAK, T., VON ROHRSCHEIDT, A. M. Military cultural tourism / Militarna turystyka kulturowa (in Polish). Warszawa: Polskie Wydawnictwo Ekonomiczne, 2011. ISBN 978-83-208-1952-6.

[17] JEDRYSIAK, T. Cultural tourism / Turystyka kulturowa (in Polish). Warszawa: Polskie Wydawnictwo Ekonomiczne, 2008. ISBN 978-83-208-1759-1.

[18] LAWIN, M., STASIAK, A. Historical and military facilities / Obiekty historyczno-wojskowe (in Polish). In: The geography of Polish tourism. A guide to sightseeing exercises. STASIAK, A. (ed.). Warszawa: PWE, 2009. EAN 9788320817690, p. 129-130.

[19] KOWALCZYK, A. Historical and military tourism / Turystyka historyczno-militarna (in Polish). In: Contenporaryforms of cultural tourism / Wspolczesne formy turystyki kulturowej. Vol. 1. BUCZKOWSKA, K., VON ROHRSCHEIDT, A. M. (eds.). Poznan: Akademia Wychowania Fizycznego im. Eugeniusza Piaseckiego w Poznaniu, 2009. ISBN 9788361414179, p. 286-312.

[20] KOWALCZYK, A. Content and form of maps used in historical and military tourism / Tresc i forma map wykorzystywanych w turystyce historyczno-militarnej (in Polish). Turystyka Kulturowa. 2018, 1, p. 95-143. ISSN 1689-4642.

[21] LIJEWSKI, T., MIKULOWSKI, B., WYRZYKOWSKI, J. The geography of Polish tourism / Geografia turstyki Polski (in Polish). Warszawa: Polskie Wydawnictwo Ekonomiczne, 2002. ISBN 978-83-208-1763-8.

[22] POCZTA, J., FIZYCZNEGO, A. W. Military tourism as a manifestation of a new form of tourism activity in Poland / Turystyka militarna jako przejaw nowej formy aktywnosci turystycznej w Polsce (in Polish). Militaria (Poligon, Bunkry, Fortyfikacje). 2008, 58, 18.

[23] CHYLINSKA, D. Modern permanent fortifications - selected problems of tourist development / Nowozytne fortyfikacje stale - wybrane problemy (in Polish). Turystyka i rekreacja. 2006, 2, p. 52-63. ISSN 1895-3700.

[24] CYNARSKI, W. Castles as the heritage of Polish fortification art and as a tourist attraction. IDO Movement for Culture. Journal of Martial Arts Anthropology. 2012, 12(4), p. 44-55. ISSN 2084-3763.

[25] STACH, E. The current use of military facilities and sites in Poland in the aspect of military cultural tourism / Aktualne wykorzystanie obiektow i miejsc militarnych w Polsce w aspekcie militarnej turystyki kulturowej (in Polish). In: New fortifications in Poland: research, realization, projects and development for modern functions / Fortyfikacje nowozytne $w$ Polsce: badania, realizacje, projekty $i$ zagospodarowanie do wspolczesnych funkcji. NAREBSKI, L. (ed.). Torun: UM Wojewodztwa Kujawsko-Pomorskiego, 2013. p. 213-223. ISBN 978-83-937545-2-6.

[26] STACH, E., PAWLOWSKA, A., MATOGA, L. Development of tourism in military-historical facilities and sites - a case study of the Rise project complexes in Gory Sowie / Rozwoj turystyki w obiektach i miejscach militarnohistorycznych - studium przypadku kompleksow projektu Riese w Gorach Sowich (in Polish). Polish Journal of Sport and Tourism. 2014, 21, p. 36-47. ISSN 1899-1998, eISSN 2082-8799.

[27] ZGLOBICKI, W. Evaluation of the offer of selected military facilities in Poland for the needs of children and youth tourism / Ocena oferty wybranych obiektow militarnych na obszarze Polski dla potrzeb turystyki dzieci i mlodziezy (in Polish). Turystyka Kulturowa. 2016, 2, p. 116-134. ISSN 1689-4642.

[28] ZAWADZKI, W. Polish military museums / Polskie muzea wojskowe (in Polish). Bydgoszcz: Przedsiebiorstwo Marketingowe "LOGO", 2002 .

[29] Commercial tourist attraction. Darwin, on Stokes Hill Wharf, Australia, Northern Territory. 2015.

[30] LEMELIN, R. H., WHYTE, K. P., JOHANSEN, K., DESBIOLLES, F. H., WILSON, C., HEMMING, S. Conflicts, battlefields, indigenous peoples and tourism: addressing dissonant heritage in warfare tourism in Australia and North America in the twenty-first century. International Journal of Culture, Tourism and Hospitality Research [online]. 2013, 7(3), p. 257-271. ISSN 1750-6182. Available from: https://doi.org/10.1108/IJCTHR-05-2012-0038

[31] CHHABRA, D., HEALY, R., SILLS, E. Staged authenticity and heritage tourism. Annals of Tourism Research [online]. 2003, 30(3), p. 702-719. ISSN 0160-738. Available from: https://doi.org/10.1016/S0160-7383(03)00044-6

[32] BIRAN, A., Hyde, K. F. New perspectives on dark tourism. International Journal of Culture, Tourism and Hospitality Research [online]. 2013, 7(3), p. 191-198 [accessed 2020-02-13]. ISSN 1750-6182. Available from: http://dx.doi.org/10.1108/IJCTHR-05-2013-0032

[33] RAINE, R. A dark tourist spectrum. International Journal of Culture, Tourism and Hospitality Research [online]. 2013, 7(3), p. 242-256 [accessed 2020-02-23]. ISSN 1750-6182. Available from: http://dx.doi.org/10.1108/IJCTHR05-2012-0037

[34] MAGEE, R., GILMORE, A. Heritage site management: from dark tourism to transformative service experience? The Service Industries Journal [online]. 2015, 35(15-16), p. 898-917. ISSN 0264-2069, eISSN 1743-9507. Available from: https://doi.org/10.1080/02642069.2015.1090980 
[35] Wolf s Lair / Wilczy Szaniec (in Polish) [online] [accessed 2020-02-23]. Available from: http://www.wilczyszaniec. olsztyn.lasy.gov.pl/aktualnosci/

[36] LAMPARSKA, J., MALIK, A. Castles / Zamki (in Polish). Warszawa: Multico Oficyna Wydawnicza, 2011.

[37] JAROSZ, J. Coastal artillery of the Polish coast. Compendium and guide / Artyleria nadbrzezna polskiego wybrzeza. Kompendium i przewodnik (in Polish). Gdynia: Wydawnictwo Region, 2018. ISBN 9788375916249.

[38] PRADZYNSKI, I. Field fortification / Umocnienie polowe (in Polish). Polscy Teoretycy Wojskowi, Wojskowy Instytut Historyczny im. Wandy Wasilewskiej. Warszawa: Wydawnictwo Ministerstwa Obrony Narodowej,1985.

[39] Polish formations and the Polish Army from 1914-1922 / Militaria polskich formacji i Wojska Polskiego z lat 1914-1922 (in Polish). Old Weapons and Colors Lovers Association, Staleczny Branch Major Franciszek Pukacki / Stowarzyszenie Milosnikow Dawnej Broni i Barwy Oddzial Stoleczny im. mjr Franciszka Pukackiego. Warszawa: Stoleczna Pracownia Dokumentacji Dobr Kultury, 1989. TIN TOO913310.

[40] Muzealnictwo wojskowe (in Polish). Muzeum Wojska Polskiego . Vol. 3. Warszawa: Wydawnictwo Ministerstwa Obrony Narodowej, 1985.

[41] Polish Army Museum. Military museums / Muzealnictwo wojskowe (in Polish) [online]. Vol. 10. Warszawa: Wydawnictwo Ministerstwa Obrony Narodowej, 2017. Available from: http://polona.pl/item/38336198

[42] Underwaterfacilities and military in the Bay of Gdansk / Obiekty podwodne i militaria Zatoki Gdanskiej (in Polish). KOMOROWSKI, A. (ed.). Gdynia: Impuls Plus Consulting, 2001. ISBN 83-7322-223-5.

[43] PIATEK, J. J. Tools of war and their modern development (selected aspects for the 20th century / Narzedzia wojny i ich wspolczesny rozwoj (wybrane aspekty dla XX wieku) (in Polish). Torun: Wydawnictwo Adam Marszalek, 2009. ISBN 9788376112671

[44]JURGA, R. M. Fortifications of the Third Reich in spatial drawings / Fortyfikacje III Rzeszy w rysunkach przestrzennych (in Polish). Czerwonak: Bialostockie Zaklady Graficzne, 2013. EAN 9788377311462.

[45] DRZEWIECKI, A., ROZYCKI, L. Pomeranian military (19th-20th century). History - education - tourism / Militaria pomorskie (XIX-XX wiek). Historia - edukacja - turystyka (in Polish). Gdansk - Oswiecim: Wydawnictwo Napoleon V, 2014.

[46] ROTTERMUND, A. Museums and Tourism / Muzea i turystyka (in Polish). In: Materials of the international conference. International Cultural Center, 1999, p. 41.

[47] Gdynska brigade of naval aviation / Gdynska brygada lotnictwa marynarki wojennej (in Polish) [online] [accessed 2018-06-01]. Available from: http://blmw.wp.mil.pl/pl/1_288.html

[48] GIETKOWSKI, M., NADOLSKI, L. Pomeranian military. Collection of studies / Militaria pomorskie. Zbior studiow (in Polish). Vol. 11. Bydgoszcz: Muzeum Wojsk Ladowych w Bydgoszczy, 2017. ISBN 978-83-64130-14-4.

[49] Muzeum Bunkier V-3 [online] [accessed 2018-06-01]. Available from: http://www.bunkierv3.pl/mapy.html

[50] Google Trends, https://rends.google.com/trends/?geo=US, accessed on 20 March 2020

[51] PODCIBORSKI, T. The method of assessing the tourist and recreational attractiveness of Warmian villages / Metoda oceny atrakcyjnosci turystyczno-rekreacyjnej wsi warminskich (in Polish). Zeszyty Naukowe Wyzszej Szkoly Ekonomiczno-Spolecznej w Ostrolece. 2016, 20, p. 22-31. ISSN 2391-9167.

[52] ZIENKIEWICZ, A. Development of the tourist function in the Kartuzy districct / Rozwoj funkcji turystycznej w powiecie kartuskim (in Polish). Warszawa: Wydzial Geografii i Studiow Regionalnych, Uniwersytet Warszawski, 2016.

[53] ZIENKIEWICZ, A. Transport infrastructure as a factor in the development of tourism in the Kartuzy district / Infrastruktura komunikacyjna jako czynnik rozwoju turystyki powiatu kartuskiego (in Polish). Slupskie Prace Geograficzne. 2017, 14, p. 281-300. ISSN 1641-8468.

[54] Gospostrateg V [online] [accessed 2021-03-20]. Available from: https://www.gov.pl/web/ncbr/gospostrateg-v 